\title{
Combination of teriflunomide and interferon as follow-up therapy after fingolimod-associated PML
}

Bettina Fischer-Barnicol, MD, Johanna Oechtering, MD, Jens Kuhle, MD, PhD, Johannes Lorscheider, MD, Ludwig Kappos, MD, and Tobias Derfuss, MD

Neurol Neuroimmunol Neuroinflamm 2021;8:e927. doi:10.1212/NXI.0000000000000927

Progressive multifocal leukoencephalopathy (PML) is one of the most important adverse events in relapsing-remitting MS (RRMS) patients treated with disease-modifying therapies (DMTs). Especially natalizumab is known to increase the risk for PML, depending on the John Cunningham virus (JCV) index in serum and the number of years on therapy with natalizumab. ${ }^{1}$ Fingolimod and dimethyl fumarate are associated with a considerably lower risk of PML. ${ }^{2}$

Currently, there is no causal treatment for PML. Stopping the DMT and thereby allowing the immune system to clear the virus from the CNS is the current clinical practice. This approach may be followed by MS disease reactivation and even an immune reconstitution inflammatory syndrome (IRIS). The conundrum of how to balance between boosting the antiviral and dampening the autoimmune response is still unresolved.

\section{Case}

We describe a 53-year-old woman diagnosed with MS based on optic neuritis, positive oligoclonal bands in the CSF, and multiple T2-hyperintense lesions with periventricular, juxtacortical, and infratentorial localization in brain MRI in December 2000. Owing to ongoing disease activity on treatment with interferon $\beta-1 b$, she was switched to fingolimod in 2011 . At this time, she had an expanded disability status score of 3.0. During the following years, she was clinically stable, but her follow-up brain MRI in November 2017 revealed subclinical disease activity with a new, non-contrast-enhancing $\mathrm{T} 2$ lesion in the periventricular region.

In March 2018, she complained about a nominal aphasia. Otherwise, the neurologic examination was unchanged. The subsequent brain MRI was highly suspicious for PML with confluent fluid-attenuated inversion recovery hyperintense lesions affecting the U-fibers in the frontal and temporal lobes (left sided) in addition to new MS-typical lesions.

All blood tests were normal except for an expected lymphopenia $(300 / \mu \mathrm{L})$ under fingolimod. CSF examination showed 341 copies/mL JCV (NIH, Bethesda, MD). Fingolimod was immediately discontinued, and she was initially treated with IV immunoglobulins $30 \mathrm{~g} / \mathrm{d}$ for 5 days. Eight weeks later, she developed worsening of her speech disorder and a slight right hemiparesis. Brain MRI (April 2018) was compatible with IRIS. She received another cycle of immunoglobulins $30 \mathrm{~g} / \mathrm{d}$ for 5 days and steroid treatment in combination with the chemokine receptor 5 antagonist maraviroc $600 \mathrm{mg} / \mathrm{d}$ for 1 month. ${ }^{3}$
Correspondence

Dr. Fischer-Barnicol Bettina.fischer-barnicol@usb.ch 

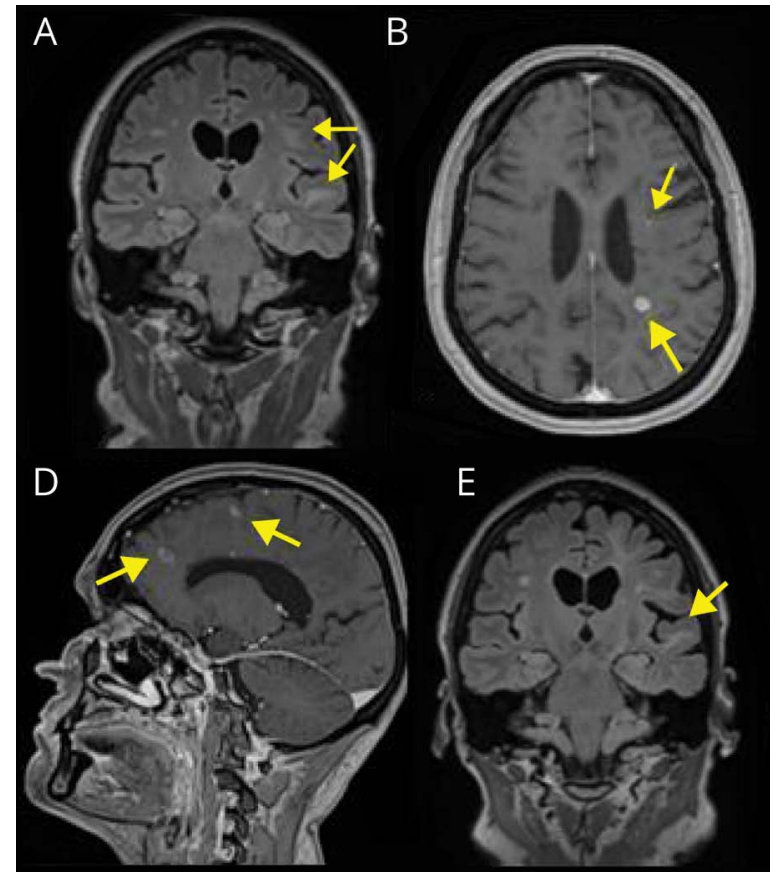

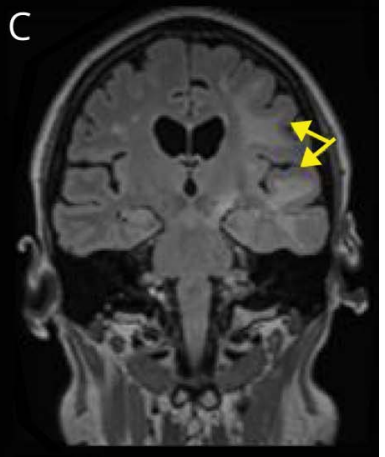

$\mathrm{F}$

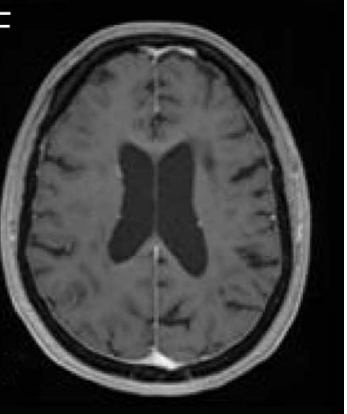

(A) (March 2018) FLAIR scan with confluent lesions involving U-fibers of left frontal and temporal lobes. (B) (March 2018) Postgadolinium T1w scan with enhancing lesions typical for MS (lower arrow) and "salt and pepper" pattern enhancement (upper arrow) suspicious for PML. (C) (May 2018) FLAIR scan showing enlarged area of increased signal indicating progression of $\mathrm{PML}$ lesions compared with March 2018 (A). (D) (May 2018) Postgadolinium T1w scan with enhancing lesions typical for MS and reflecting IRIS (lower arrow) and lesions typical for PML (upper arrow) can be seen. (E) (January 2019) FLAIR scan with significant decrease of the hyperintense area. (F) Postgadolinium T1w scan: no detectable enhancement. FLAIR = fluid-attenuated inversion recovery, IRIS = immune reconstitution inflammatory syndrome, $\mathrm{PML}=$ progressive multifocal leukoencephalopathy, T1w = T1 weighted.
Under this treatment IRIS improved, but new MS lesions were observed in a brain MRI in May 2018. In June 2018, CSF analysis revealed 23 copies $/ \mathrm{mL}$ of JCV. Teriflunomide was started because of continuing MS disease activity in July 2018.
Repeated CSF analysis in September 2018 showed complete clearance of JCV, and the patient recovered partially from the PML-related symptoms, with only intermittent nominal aphasia. The clinical and MRI follow-ups in January 2019

Figure 2 Time course of serum NfL levels

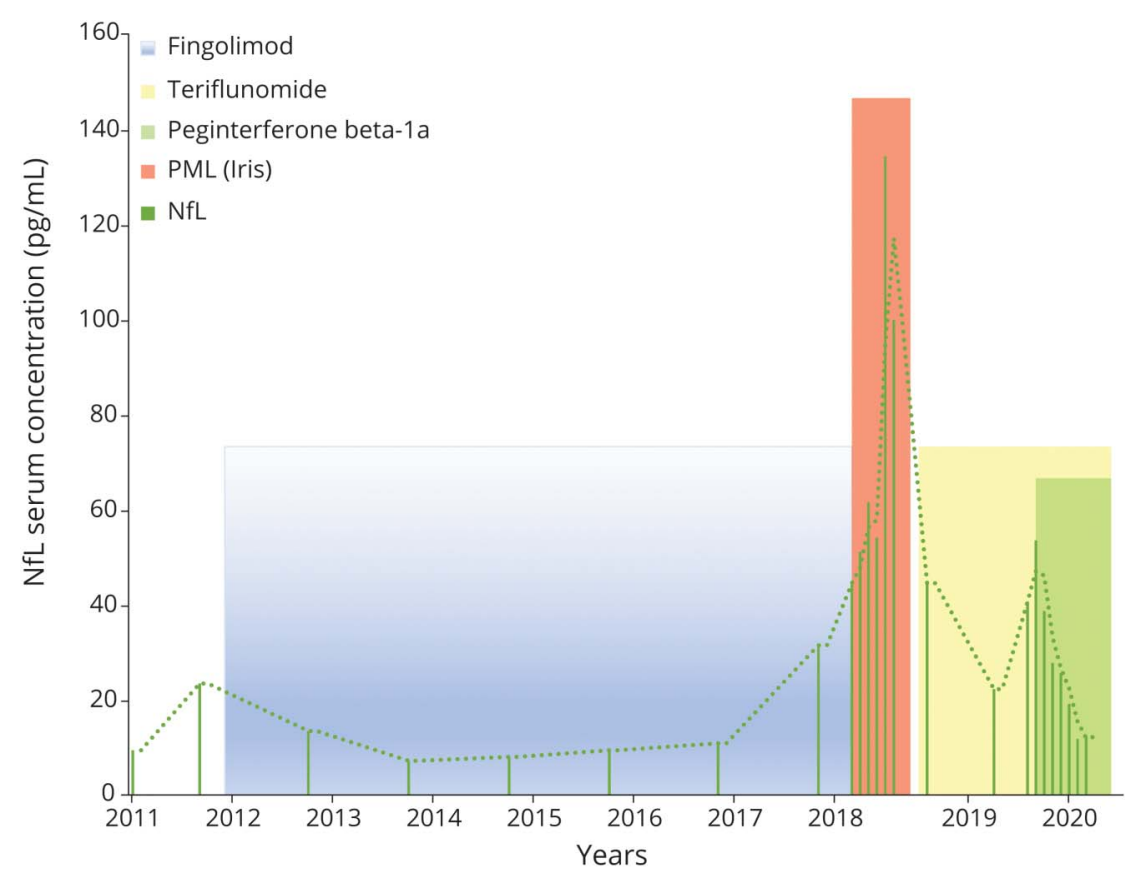

IRIS = immune reconstitution inflammatory syndrome; $\mathrm{NfL}=$ neurofilament light chain; $\mathrm{PML}=$ progressive multifocal leukoencephalopathy. 
showed no new neurologic symptoms and no indication of new PML-related lesions, but on-going MS activity. Therefore, peg interferon $\beta$-1a was added to teriflunomide in September 2019. MRI in December 2019 and February 2020 showed no signs of new MS disease activity.

Mirroring the clinical and MRI findings, neurofilament light chain (NfL) remained stable and low during fingolimod treatment but increased in November 2017 when a new lesion was detected in MRI (figure $1 G$ ). During PML, there was a further dramatic increase of NfL with maximum levels measured in April 2018 that coincided with radiologic IRIS manifestation. On IRIS treatment and start of teriflunomide, NfL levels decreased but were still high in comparison to 2011, correlating with increased MRI activity (figure 2). Adding peg interferon $\beta$-1a to teriflunomide was paralleled by a decrease in NfL levels and a stabilization of MRI.

\section{Discussion}

Teriflunomide, which is registered for the treatment of RRMS, is the active metabolite of leflunomide. Case reports and cohort studies in the field of kidney transplantation have indicated that leflunomide might be effective in enabling clearance of the $\mathrm{BK}$ virus (BKV) while still preserving immunosuppression to prevent rejection of the graft. ${ }^{4-6} \mathrm{BKV}$ and JCV both belong to the family of Polyomaviridae. Under the hypothesis that teriflunomide might not worsen PML, we chose teriflunomide as a follow-up DMT. Under teriflunomide treatment, the JCV PCR became negative in the CSF, NfL levels decreased, and follow-up MRIs did not show evidence of recurring PML, but ongoing MS disease activity. Owing to continuing MS disease activity in combination with further increasing NfL levels, we escalated the treatment by adding peg interferon $\beta$-1a, which provides another mode of action compared with teriflunomide and is not associated with an increased risk for PML. As shown in a phase II trial, this combination treatment was well tolerated, and it was associated with a further decrease of NfL in our patient. ${ }^{7}$

We conclude that-although teriflunomide has no proven antiviral effect-it at least did not worsen PML. In combination with interferon, it might be a safe treatment option in patients recovering from PML to prevent recurring MS activity.

\section{Study funding}

No targeted funding reported.

\section{Disclosure}

B. Fischer-Barnicol has received travel grants from Biogen and Novartis and served on a scientific advisory board for Roche, not related to this work. J. Oechtering has received travel grants from Bayer, Biogen, and Novartis and served on a scientific advisory board for Roche, not related to this work. J. Kuhle received speaker fees, research support, travel support, and/or served on advisory boards by the Swiss MS Society, Swiss National Research Foundation (320030 160221), University of Basel, Biogen, Celgene, Merck, Novartis, Roche, Sanofi. J. Lorscheider received research support from Innosuisse-Swiss Innovation Agency, Biogen, and Novartis; he served on advisory boards for Biogen, Novartis, Roche, and Teva. L. Kappos' institution (University Hospital Basel) has received research support and payments that were used exclusively for research support for L. Kappos' activities as principal investigator and member or chair of planning and steering committees or advisory boards in trials sponsored by Actelion, Addex, Almirall, Bayer HealthCare, Celgene, CLC Behring, Genentech, GeNeuro, Genzyme, Merck Serono, Mitsubishi Pharma, Novartis, Octapharma, Ono, Pfizer, Receptos, F. Hoffmann-La Roche, Sanofi- Aventis, Santhera, Siemens, Teva, UCB, and XenoPort; licence fees for Neurostatus 4 products; research grants from the Swiss MS Society, the Swiss National Research Foundation, Innoswiss, the European Union, and the Roche Research Foundation. T. Derfuss serves on scientific advisory boards for Novartis, Merck, Biogen, Genzyme, GeNeuro, Mitsubishi Pharma, Actelion, Roche, Alexion, and Celgene; has received funding for travel and/or speaker honoraria from Biogen, Genzyme, Novartis, Merck, and Roche; and received research support from Biogen, Novartis, Roche, the European Union, the Swiss National Science Foundation and the Swiss MS Society. Go to Neurology. org/NN for full disclosures.

\section{Publication history}

Received by Neurology: Neuroimmunology \& Neuroinflammation June 6, 2020. Accepted in final form September 30, 2020.

\section{Appendix Authors}

\begin{tabular}{lll}
\hline Name & Location & Contribution \\
\hline $\begin{array}{l}\text { Bettina } \\
\text { Bischer- }\end{array}$ & $\begin{array}{l}\text { University Hospital of } \\
\text { Basel, University of } \\
\text { Basel, Switzerland }\end{array}$ & $\begin{array}{l}\text { Analyzed the data and } \\
\text { drafted the manuscript for } \\
\text { intellectual content }\end{array}$ \\
\hline $\begin{array}{l}\text { Johanna } \\
\text { Oechtering, } \\
\text { MD }\end{array}$ & $\begin{array}{l}\text { University Hospital of } \\
\text { Basel, University of } \\
\text { Basel, Switzerland }\end{array}$ & $\begin{array}{l}\text { Analyzed the data and } \\
\text { drafted the manuscript for } \\
\text { intellectual content }\end{array}$ \\
$\begin{array}{l}\text { Jens Kuhle, } \\
\text { MD, PhD }\end{array}$ & $\begin{array}{l}\text { University Hospital of } \\
\text { Basel, University of }\end{array}$ & $\begin{array}{l}\text { Interpreted the data and } \\
\text { revised the manuscript for } \\
\text { intellectual content }\end{array}$ \\
$\begin{array}{l}\text { Basel, Switzerland } \\
\text { Lohannes } \\
\text { MD }\end{array}$ & $\begin{array}{l}\text { University Hospital of } \\
\text { Basel, University of } \\
\text { Basel, Switzerland }\end{array}$ & $\begin{array}{l}\text { Interpreted the data and } \\
\text { revised the manuscript for } \\
\text { intellectual content }\end{array}$ \\
$\begin{array}{l}\text { Ludwig } \\
\text { Kappos, MD }\end{array}$ & $\begin{array}{l}\text { University Hospital of } \\
\text { Basel, University of } \\
\text { Basel, Switzerland }\end{array}$ & $\begin{array}{l}\text { Interpreted the data and } \\
\text { revised the manuscript for } \\
\text { intellectual content }\end{array}$ \\
$\begin{array}{l}\text { Tobias } \\
\text { Derfuss, MD }\end{array}$ & $\begin{array}{l}\text { University Hospital of } \\
\text { Basel, University of } \\
\text { Basel, Switzerland }\end{array}$ & $\begin{array}{l}\text { Interpreted the data and } \\
\text { revised the manuscript for } \\
\text { intellectual content }\end{array}$ \\
\hline
\end{tabular}




\section{References}

1. Plavina T, Subramanyam M, Bloomgren G, et al. Anti-JC virus antibody levels in serum or plasma further define risk of natalizumab-associated progressive multifocal leukoencephalopathy. Ann Neurol 2014;76:802-812.

2. Berger JR, Cree B, Greenberg B, et al. Classifying PML risk with disease modifying therapies. Mult Scler Relat Disord 2017;12:59-63.

3. Bsteh G, Auer M, Iglseder S, et al. Severe early natalizumab-associated PML in MS: effective control of PML-IRIS with maraviroc. Neurol Neuroimmunol Neuroinflamm 2017;4:e323. doi: 10.1212/NXI.0000000000000323.
4. Yang D, Keys B, Conti D, et al. JC-polyomavirus nephropathy, a rare cause of transplant dysfunction: case report and review of literature. Transpl Infect Dis 2017;19:e12654.

5. Johnston O, Jaswal D, Gill JS, Doucette S, Fergusson DA, Knoll GA. Treatment of polyomavirus infection in kidney transplant recipients: a systematic review. Transplantation 2010;89:1057-1070.

6. Chacko B, John GT. Leflunomide for cytomegalovirus: bench to bedside. Transpl Infect Dis 2012;14:111-120.

7. Freedman MS, Wolinsky JS, Wamil B, et al; Teriflunomide Multiple Sclerosis Trial Group and the MRI Analysis Center. Teriflunomide added to interferon- $\beta$ in relapsing multiple sclerosis: a randomized phase II trial. Neurology 2012;78:1877-1885. 


\title{
Neurology $^{\odot}$ \\ Neuroimmunology \& Neuroinflammation
}

\author{
Combination of teriflunomide and interferon as follow-up therapy after \\ fingolimod-associated PML \\ Bettina Fischer-Barnicol, Johanna Oechtering, Jens Kuhle, et al. \\ Neurol Neuroimmunol Neuroinflamm 2021;8; \\ DOI 10.1212/NXI.0000000000000927
}

This information is current as of December 3, 2020

Updated Information \&

Services

References

Subspecialty Collections

Permissions \& Licensing

Reprints including high resolution figures, can be found at:

http://nn.neurology.org/content/8/1/e927.full.html

This article cites 7 articles, 1 of which you can access for free at: http://nn.neurology.org/content/8/1/e927.full.html\#\#ref-list-1

This article, along with others on similar topics, appears in the following collection(s):

Multiple sclerosis

http://nn.neurology.org//cgi/collection/multiple_sclerosis

Viral infections

http://nn.neurology.org//cgi/collection/viral_infections

Information about reproducing this article in parts (figures,tables) or in its entirety can be found online at:

http://nn.neurology.org/misc/about.xhtml\#permissions

Information about ordering reprints can be found online: http://nn.neurology.org/misc/addir.xhtml\#reprintsus

Neurol Neuroimmunol Neuroinflamm is an official journal of the American Academy of Neurology.

Published since April 2014, it is an open-access, online-only, continuous publication journal. Copyright

Copyright (C) 2020 The Author(s). Published by Wolters Kluwer Health, Inc. on behalf of the American

Academy of Neurology.. All rights reserved. Online ISSN: 2332-7812.

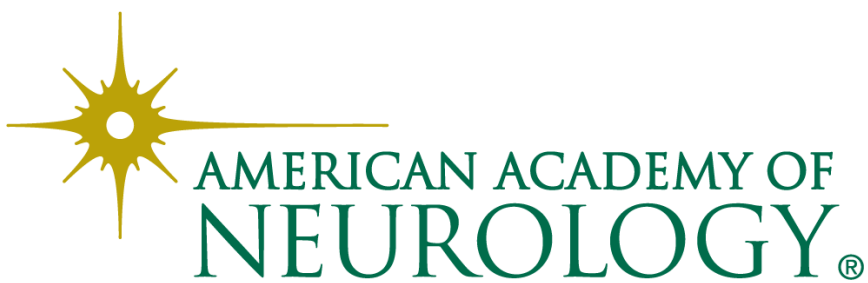

